\title{
Institutional Factors of Competitiveness and Development of the National Economy
}

\author{
Valentyna Stadnyk \\ Department of Management, \\ of Administration and Hotel \\ and Restaurant Business, \\ Khmelnitskyi National University, \\ Khmelnitskyi, Ukraine \\ stadnyk_v_v@ukr.net \\ http://orsid.org/0000-0002-2095-3517
}

\author{
Galyna Sokoliuk \\ Department of Management, \\ of Administration and Hotel \\ and Restaurant Business, \\ Khmelnitskyi National University, \\ Khmelnitskyi, Ukraine \\ sokoliukg@gmail.com \\ Olha Matviiets \\ Department of International \\ Economic, \\ Khmelnitskyi National University, \\ Khmelnitskyi, Ukraine \\ olrebak@ukr.net
}

\author{
Andriy Goncharuk, \\ Department of Economics, Management \\ and Administration, \\ Khmelnitskyi National University, \\ Khmelnitskyi, Ukraine \\ goncharukam@gmail.com
}

\begin{abstract}
The problem of increasing the competitiveness and development of the Ukrainian economy has been updated. It has been argued that this problem can be addressed in the context of institutional change - by eliminating the discrepancy between formal and informal components of the institutional environment. The main gaps in the institutional environment of Ukraine, which determine the dominance of the corruption component in the decisions and actions of various economic agents - representatives of business, legislative and executive authorities have been highlighted. On the basis of the analysis of Ukrainian machine-building enterprises products export dynamics in 2001-2018, the decrease of its competitiveness in foreign markets has been proved. It has been proved by comparative analysis of corruption perception and competitiveness indexes with composition of national economies innovation indexes that the main reason for the Ukrainian economy competitiveness low level is the regulatory structures inefficient activity. It has been stated that this situation is caused by a motivational imbalance between the amount of powers and the responsibility of their employees, which gives rise to the development of the shadow service sector (corruption). This compensates the absence of legal institutions of collective action (lobbying institutes, elements of innovative infrastructure). The conditions under which the business community would be interested in the development of collective action institutions have been identified
\end{abstract}

Keywords - institutional environment, institutional gaps, corruption, innovation index, motivational imbalance, collective action institutions

\section{INTRODUCTION}

Development is an inherent characteristic of the dynamic state of any socio-economic system, which is determined by the goals of its functioning. Development provides it with the ability to adapt to the new conditions in which it must function according to its purpose in the next time period.

With a highly volatile and highly competitive business environment that distinguishes the modern global market, managing the development of businesses, industries and entire regions must be paramount to enhancing the competitiveness of the national economy. The urgency of this task for Ukraine, which seeks to increase its presence in the world market (with high-tech goods, not raw materials), is beyond doubt and requires methodological justification of the conditions and mechanisms for its solution for all participants of economic activity.

Obviously, the problem of maintaining and increasing competitiveness will continue to be urgent for all market economy entities that work in market conditions. At the same time, the forms and vectors of competitive confrontation, as well as their effectiveness, depend to a large extent on those parameters of the market environment that are formed under the influence of institutional factors, in particular, in the legislative field of the country. They determine the "rules of the game" of economic agents in the relevant economic space: from general rules that must be adhered to by all, and to specific, that deal with specific industry or regional conditions of activity that require a specific approach to regulating them. For this reason, the matter of linking the characteristics of a country's institutional environment with the ability of its economic entities to compete on equal with similar entities in the global economic space is extremely important and relevant to the study, since identifying the cause-and-effect relationships in economic processes makes it possible to effectively influence their progress in order to achieve positive results in terms of the management subject's interests.

Issues of the influence of institutional factors on economic processes are in the field of view of scientists since the beginning of the twentieth century. However, a special interest in them arose after the collapse of the USSR, when it became apparent that different countries, having changed the planning and administrative mechanism of economic management on the market, achieved different results in the course of their socio-economic development. Following the publication by D. North of his fundamental work "Institutions, Institutional Change, and the Functioning of the Economy"[1], both formal and informal components of the institutional environment were in the zone of increased attention of post-Soviet scholars. However, they have been considered largely at the macroeconomic level in the context of the development of national economies as integral socio- 
economic systems. In particular, V. Volchyk [2], A. Hrytsenko [3], V. Dementyev [4], G. Kirdina [5], G. Kleiner [6], R. Nureyev [7], Y. Olsevych [8], V. Polterovych [9], L.Tomilina [10] and many others carried out an active scientific search in the early 2000s. They examined the features of the influence of institutions on the formation of the system of government [4] and social processes [2], [6], [8], investigated the vectors and the power of their influence on the overall economic growth [2], [8], [10], the causes of institutional traps [9], opportunities for designing of institutional changes [6], [7], proposed the theory of institutional matrices [5], developed recommendations for research and improvement of institutional architectonics of economic systems [3] and many more.

Recently, the studies of institutional scholars have focused on the influence of institutional factors on the competitiveness of socio-economic systems (primarily due to the improvement of conditions for innovative entrepreneurship), but the national economy has also been the focus of research. In particular, in Ukraine, the most recent publications on these issues include those of L Piddubna [11], P. Leonenko [12], V. Zapuhlyak [13], O. Zubchyk [14]; some aspects of these issues at the regional level are covered in the works of I. Irtyshcheva and D. Krylenko [15], in the sectoral section - V. Skupeyko [16]. At the same time, relevant research is also important at the micro level, in terms of types of economic behavior of businesses with respect to competitors which are formed in a particular institutional environment and how this affects the state and dynamics of the national economy development as a whole. For Ukraine, these issues are particularly relevant, as the dynamics of its socio-economic development, unfortunately, do not meet the requirements of time and social expectations. This determined the purpose of this study.

The purpose of the paper is detection of gaps in the domestic institutional environment, that predetermine in the economic processes the dominance of such type of economic behavior against competitors, which containing the corruption component and determining how it affects the conditions and dynamics of the development of the national economy as a whole.

\section{ReSEARCH Methodology}

By the methods of scientific abstraction and logical generalization it has been highlighted the main gaps in the institutional environment of Ukraine, which determine the dominance of the corruption component in the decisions and ways of their realization by economic agents. Methods of comparative analysis have been used to illustrate the link between the level of corruption perception and the national economies competitiveness. The dynamics of Ukrainian machine-building enterprises export performance during 2001-2018 has been investigated by economic and statistical analysis methods. Mathematical modeling techniques have been used to formalize the conditions under which the business community will be interested in developing of collective action institutions (innovative infrastructure).

\section{RESULTS}

Institutional factors along with traditional production are increasingly recognized now as determining the competitiveness of socio-economic systems. This is especially emphasized by representatives of the evolutionary-institutional economic theory, who determine the effectiveness and efficiency of economic processes by dominating characteristics of their social component [3], [6], [8]. After all, the more participants in joint economic activities, the more efforts are necessary to be made by the management link for coordination their actions and to aim them on achieving the goals set by management. For this purpose certain rules that regulate the behavior of the structural elements of the system are formed, these are institutions. «It is the institutions (in their classical sense as a set of formal and informal rules and regulations) are the environment where economic laws manifest themselves; it is through the institutions economic policy expresses itself. At the same time, institutions, as factors of spiritual, cultural, ideological and political nature, shape the content of economic policy, ... actively influencing the nature of economic development», D. North noted [1].

The set of institutions of the socio-economic system forms an institutional environment, which is considered by modern scholars as an institution, but of a special kind - as a matrix of higher order development, on the basis of which the formation and selection of the most effective economic and social institutions take place [5]. Depending on the characteristics of the institutional environment, the development of the socio-economic system may occur in different scenarios and have different dynamics and different results.

Moreover, if the process of institutional change took place without a well-thought-out strategy, in which there would be a clear vision of linking the new instruments of legislative regulation of economic activity with the desired results of general socio-economic development, as was the case in Ukraine.

We have suggested that not only the imperfection of the institutional environment in terms of forming the legislative field of economic activity is the reason for this, but also the low effectiveness of regulatory structures that give rise to the negative phenomena in society which are called corruption.

As the course of the transformation of the planned and administrative economy of Ukraine into a market showed, the formation of market institutions (in particular, the legislative base) was carried out not only by trial and error, but by a powerful lobbying of the interests of those business representatives who could use certain levers of influence on the authorities for creation of preferences for affiliated with them business structures. As a result, subparagraphs subclauses of "exceptions" for individual commodity producers in pricing, taxing or gaining access to scarce resources appeared in the enacted legislation. This allowed them to gain relevant competitive advantages - both domestically and globally. Under these conditions, preference holders did not need to pursue an active innovative search, which in today's globalized world is the main source of competitive advantages, as well as a tool for predicting promising areas of business development. Therefore, most of the provisions of the Law of Ukraine "On Innovation Activities" and the corresponding Decrees of the Cabinet of Ministers and Decrees of the President of Ukraine are mostly declarative in nature and not supported by specific financial instruments for their implementation. 
In order to eliminate unjustified preferences, new legislative changes were initiated, which often were fragmented and could not significantly change the situation because they did not take into account the general macroeconomic trends. Moreover, they were not supported by changes in regulatory mechanisms, which made it impossible to provide effective state government enforcement. Over time, such institutional gaps created the conditions for the formation and diversification of the various types of corruption schemes that manifested in the decisions of management and business owners. This is summarized by us in Table 1.

TABLE I. THE INSTITUTIONAL NATURE OF THE CORRUPTIVE COMPONENT DEVELOPMENT IN THE BUSINESS ENVIRONMENT OF UKRAINE

\begin{tabular}{|c|c|}
\hline $\begin{array}{c}\text { The institutional nature of } \\
\text { the problem }\end{array}$ & $\begin{array}{c}\text { Influence of the business } \\
\text { environment institutional } \\
\text { imperfection on decisions and } \\
\text { actions of business structures } \\
\text { management }\end{array}$ \\
\hline $\begin{array}{l}\text { At the beginning of market } \\
\text { transformations, the state was } \\
\text { eliminated from building of } \\
\text { the civilized competition } \\
\text { environment }\end{array}$ & $\begin{array}{l}\text { Forced application of unofficial rules } \\
\text { and illegal ways of enforcement for } \\
\text { regulation of relations in the field of } \\
\text { competition }\end{array}$ \\
\hline $\begin{array}{l}\text { Opacity and high level of } \\
\text { corruption in the formation of } \\
\text { the legislative base of } \\
\text { competitive relations }\end{array}$ & $\begin{array}{l}\text { Self-interest lobbying in the } \\
\text { authorities, including the use of illegal } \\
\text { methods and ways of influence }\end{array}$ \\
\hline $\begin{array}{lr}\text { Insufficient } & \text { institutional } \\
\text { support of } & \text { property rights } \\
\text { protection, } & \text { including } \\
\text { intellectual } & \end{array}$ & $\begin{array}{l}\text { Reluctance to invest in a long-term } \\
\text { projects of innovative development, } \\
\text { intellectual resources depreciation }\end{array}$ \\
\hline $\begin{array}{l}\text { The imperfection of economic } \\
\text { activity institutional } \\
\text { regulation, which causes } \\
\text { uneven conditions of } \\
\text { competition for different } \\
\text { economic entities }\end{array}$ & $\begin{array}{l}\text { The effort to create and use } \\
\text { preferences to their own advantage } \\
\text { (targeting of privileges, debt relief, } \\
\text { government guarantees for } \\
\text { commercial loans, availability of free } \\
\text { economic zones, high customs tariffs, } \\
\text { etc.) }\end{array}$ \\
\hline $\begin{array}{l}\text { Information asymmetry about } \\
\text { the state of the market due to } \\
\text { underdeveloped market } \\
\text { infrastructure }\end{array}$ & $\begin{array}{l}\text { Dissemination of the cyber attacks } \\
\text { practice and other ways of finding } \\
\text { insider information to combat } \\
\text { competitors }\end{array}$ \\
\hline Underdeveloped civil society & $\begin{array}{l}\text { High level of economic activity } \\
\text { shadowing for improvement of } \\
\text { competitive positions, spread of non- } \\
\text { civilized methods of competition }\end{array}$ \\
\hline $\begin{array}{l}\text { A mental gap in the society } \\
\text { about the content and } \\
\text { methods of competition and } \\
\text { the treatment of social justice }\end{array}$ & $\begin{array}{l}\text { Increasing of the exploitation level } \\
\text { and reducing of the social protection } \\
\text { of workers }\end{array}$ \\
\hline
\end{tabular}

Therefore, corruption is a specific component of the institutional environment, driven by its imperfection. It's not only the gaps in the current legislation that are made possible by the ambiguous interpretation of some of its norms, but also the result of a deliberate distortion of the legislative field in favor of particular interest groups with significant economic resources who effectively lobby for their own interests.

In the legislative field, under the influence of shadow lobbying, there are constantly appearing systemic "holes" that are quite legal, although not obvious to the general public. And it frees from legal liability those who see their corruption opportunities and can use them themselves or advise to others. At the same time, it creates favorable conditions for further "legislative ingenuity", expanding and nourishing the field to design new revenue schemes that can only be conditionally attributed to honest ones.

We see examples of such schemes in the Ukrainian business environment everywhere. And, for example, the spread of tax optimization practices is not only a barrier to budget filling, but it also hinders the growth of business entities, since large business structures are deliberately shredded for such optimization. As we have noted in our previous work [17], the processes of disintegration in the Ukrainian economy are a reaction of business to the deterioration of its operating conditions, especially in the field of taxation. Therefore, in recent years, there has been a tendency towards a decline in the share of large enterprises and in the production of all types of products. If in 2012, this share was $49.1 \%$, then in 2016 - only $40.7 \%$; during the same period in industry, the share decreased from $68.3 \%$ to $55.4 \%$, and in agriculture from $13.3 \%$ to $12.4 \%$ (with the fact that in 2015 large agricultural enterprises raised $16,8 \%$ of the total volume of agricultural products) [18].

Granting of certain preferences to one economic player is often unreasonable, contrary to the public interest, causing structural imbalance in the development of the national economy. That is, at the macroeconomic level there is an imbalance between the development of individual industries or regions, which violates the self-sufficiency and competitiveness of the economic system as a whole. This is manifested, in particular, in the deformation of the export potential towards the commodity turnover, which leads to environmental problems and does not contribute to the growth of intellectual capital of the country, and vice versa causes the degradation of labor force.

In Ukraine, for example, such trends are gaining more and more sustainability. As a result, it also adversely affects the ability to function effectively to those economic players whose interests were initially favored. Yes, many business structures are already experiencing a lack of highly qualified employees, which means that their ability to create high value-added products, technological development and innovative production upgrade is lost.

Another important factor in the development of corruption is low effectiveness of the institutional regulatory mechanism, when there is no or poorly traceable link between the actions of the executive of regulatory functions and his responsibility for the result of the implementation of these functions. Moreover, it is manifested along the entire vertical of public administration. This irresponsibility, combined with the low level of remuneration, compels the regulated entity (civil servant) to make decisions based on his or her interests. And quite often the decisions made are not socially useful.

That is, it can be argued that corruption at the executive level is the result of the inability of the country's institutional environment to ensure the fulfillment of its basic regulatory function - motivational. If the incentives and anti-incentives contained in the regulatory mechanism (enforcement mechanisms) are not significant enough to influence the behavior of economic agents in the direction determined by the regulatory acts, they will be guided in their decisions and actions primarily by their own interests. For these reasons, the corruption component in the civil servants' environment is very significant today. This is confirmed by Transparency 
International's Corruption Perceptions Index (CRI), which ranks the 120th for Ukraine in the world ranking with 32 points (100 points indicating that there is almost no corruption in the country and 0 points that corruption actually replacing the state) [19].

As for corruption at the legislative level, its nature is also institutional as lobbying institutions in Ukraine exist outside the legal field, but they are quite powerful. However, the existence of them in a non-legal status makes it impossible to carry out a qualified examination of the results of the implementation of their lobbied laws from the point of view of maximization of public interest.
Such laws are adopted by consensus with other stakeholder groups, and the public interest in these negotiations is largely sidelined and does not make the main argument, when the wrong decision can be prevented. Given that the most powerful stakeholder groups in Ukraine are the owners (or managers) of raw materials, and lobbying their interests through the legislature further unbalances the structure of the national economy, deepening its commodity specialization. Confirmation of this, for example, is the constant Ukraine's decline in exports of machine-building products (Figure 1)

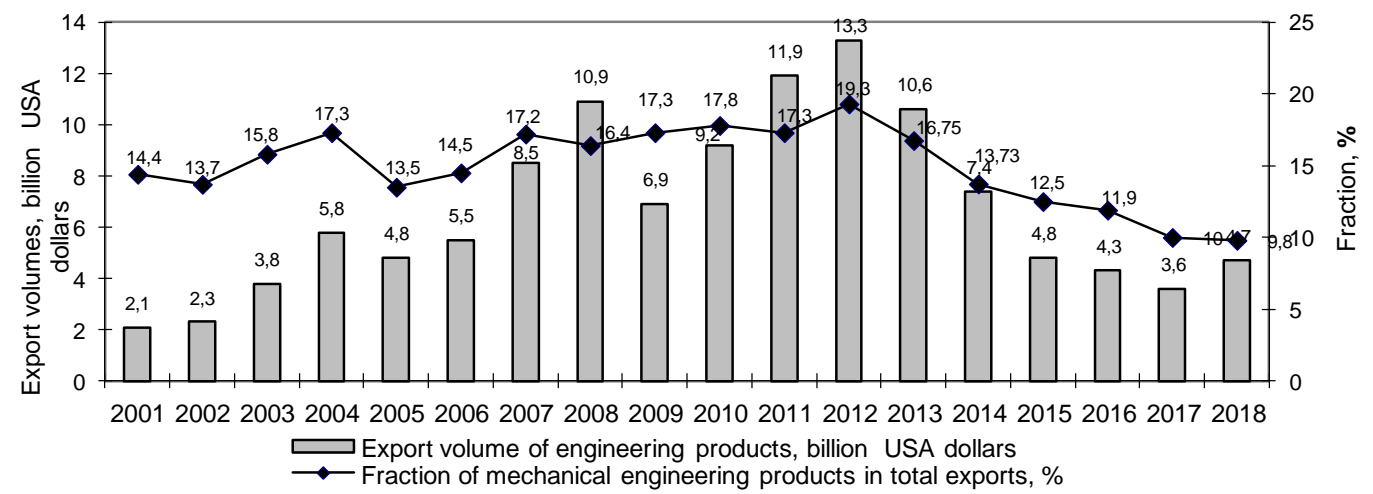

Fig. 1. Dynamics of Ukraine machine-building products export (built by [20])

It is worth noting that it is in the manufacture of machine-building products that the largest share of value added is created. However, the development of this industry is the most capital-intensive and risk-dependent, which makes machine-building unattractive for potential investors. At the same time, the industry is of great social importance, creating a large number of jobs and requiring highly qualified personnel in the field of engineering and invention. And no less skilled personnel in the field of marketing communications both for research of market needs, and for positioning of the created novelties in the market. These tasks require a complex approach and comprehensive support at the institutional level, first of all, through grounded preferences in the field of taxation and crediting of technological upgrading (equipping) of production systems.

In addition, due to the lack of a branched and diverse innovation infrastructure that would provide institutional support for the development of small and medium-sized enterprises, the innovative activity of Ukrainian producers is diminished every year and their ability to produce high value-added products is lost. As a result, the structural imbalance of the Ukrainian economy is growing, which also affects its competitiveness. According to The Global Competitiveness Index in 2018, Ukraine ranked 81st out of 180 countries. This is despite the fact that it ranked 43rd out of 126 countries (38.5 points) in 2018 according to the Innovation Index, ahead of Russia (46th place, 37.9 points). In 2019, Ukraine lost several positions and ranked 47th out of 129 countries, gaining 37.4 points (Switzerland being first with 68.4 points) [21].
If we analyze the components of the Global Innovation Index of Ukraine, it will become clear that the main positions that significantly lower the rating lie in the institutional field - legislative, organizational and regulatory. These are the rule of law (107th place) and the effectiveness of government (95th position). Directly stemming from the imperfection of the institutional environment is political and operational stability -125 th place, investment -115 th. And the best positions are in the field of intellectual property (intangible assets, patents, inventions -17 th, including utility models 1st place) [21].

That is, the figures show that the potential for creating new knowledge in Ukraine is not yet exhausted, but the conditions for its implementation are unfavorable primarily because of the imperfection of the institutional environment, because of the gaps in it that motivate the creation of corruption schemes both in the legislative and in the executive branches of state government.

In our opinion, both institutional gaps can be eliminated by building an effective enforcement system that is classically interpreted as "enforcement to implementation." However, in our point of view, it is a wrong position that enforcement should dominate in this system. It should include a valent motivational component directly related to the effectiveness of lawmaking or administrative activity, which is defined in terms of public utility.

This can be exemplified by the formation of a motivational basis for the development of innovative infrastructure, such as business incubators or technology transfer centers. This task is now within the area of 
responsibility of regional state authorities and local government bodies and their decision is directly influenced by institutional factors, in particular:

- loyalty of the public to the shadow activity of entrepreneurs;

- low efficiency of regulatory structures, which are obliged to control entrepreneurial activity and counteract shadow schemes;

- the inconsistency of the content of the functions performed by the elements of the infrastructure with those that are really needed to accelerate the process of starting or developing a business (due to both lack of adequate material and technical base and insufficient efficiency of consulting services).

Based on the above, it can be stated that the condition under which certain elements of the innovation infrastructure will be required by the business is the excess of the received profit of the entrepreneur from the use of their services $\left(P_{\text {ic }}\right)$ over the income that he will have, working independently in the current legal field $\left(P_{\text {leg }}\right)$ or resorting more or less to shadow schemes $\left(P_{\text {ileg }}\right)$.

$$
\left(P_{i c}+P_{\text {leg }}\right)>P_{\text {ileg }}
$$

If inequality with the opposite sign occurs, that is, independent work (including the use of shadow schemes) provides entrepreneurs with better results than using the services of collective action structures, then business interest in the development of such elements of innovative infrastructure will be absent.

Increasing the efficiency of collective action structures, can have a positive impact on the formation of a civilized institutional environment, since reducing the income gap using illegal and legal schemes will entice entrepreneurs to choose the second alternative, which is more psychologically acceptable to the majority.

\section{CONCLUSIONS}

Dynamics of the global economic space expansion makes the problem of socio-economic development of Ukraine inseparable from the problem of its economy competitiveness. The dialectics of this relationship are obvious and need to take into account all cause and effect relationships.Based on the methodology of evolutionaryinstitutional theory, the paper proves that there is a direct relationship between the components of competitiveness (viability) of the socio-economic system and the quality of institutions that regulate its social relations (institutional matrix).

In the process of the Ukraine institutional environment analysis, the discrepancies between its formal and informal institutions, which determine the dominance of the corruption component in the decisions and actions of various economic agents - representatives of business, legislative and executive power has been highlited. The results of the comparative analysis of corruption perception and competitiveness indexes with composition of national economies innovation indexes showed that one of the reasons for the low level of competitiveness of the Ukrainian economy is the inefficient activity of regulatory structures, due to a motivational imbalance between the scope of authority and the performers responsibility. This gives rise to the development of the shadow service sector (corruption), which compensates the absence of collective action legal institutions. The conditions under which the business community will be interested in the development of collective action institutions are identified.

\section{REFERENCES}

[1] North, Douglass, Institutions, Institutional Change, and Economic Performance, New York: Cambridge University Press, 1990.

[2] V. V. Volchik, "Narrative and Institutional Economics", Journal of Institutional Studies, no. 9 (4), pp. 132-143, 2017.

[3] A. A. Gritsenko "Institutional architectonics: object, theory and methodology", Post-Soviet Institutionalism: Monograph: [Ed. P. M. Nureyev, V. V. Dementiev]. Donetsk: "Chestnut”, pp. 49-74, 2005.

[4] V.V. Dementiev, "What are we studying when we study institutions?", Terra Economicus, no. 7, pp. 13-30, 2009.

[5] S Kirdina, "Methodological individualism and methodological institutionalism", Voprosy economiki, no. 10, 2013.

[6] G. B. Kleiner, "From the "economy of individuals" to a systemic economy”, Economic Issues, vol. 8, 2017.

[7] R. Nureyev, "Neoinstitutional methodology" Problems of Economics, no. 8, pp. 127-132, 2002.

[8] Yu. Olsevich, and V. Mazarchuk, "On the specifics of economic institutions of the social sphere", Issues of Economics, no. 5, pp. 5064, 2005.

[9] V. M. Polterovich, "Institutional traps and economic reforms", Economics and mathematical methods, is. 2, vol. 35, pp. 3-20, 1999.

[10] L.V. Tomilina, "Investigation of the role of institutional determinants of economic growth in countries with economies in transition", PostSoviet Institutionalism: Monograph: [Ed. P.M. Nureyev, V.V. Dementiev], Donetsk: "Chestnut”, pp. 309-325, 2005.

[11] L.I. Piddubna, Competitiveness of economic systems: theory, mechanism of regulation and management, Kharkiv: INZHEK, 2007.

[12] P. M. Leonenko, "Institutional Aspects of Innovative Entrepreneurship and Competitiveness of the Ukrainian Economy", Finance of Ukraine, no. 10, pp. 89-112, 2016.

[13] V. Zapuhlyak, "Institutional inertia and competitiveness of the economy", Sustainable development of local communities: the role of economic education and science", materials of the scientific-practical conference (Nov. 9-10, 2017 - Chernivtsi: ChNU), pp. 26-29, 2017.

[14] O. A. Zubchik, "Institutional foundations of Ukraine's competitiveness as a factor in national security", Scientific journal of the National Security Academy, no. 3-4, pp. 128-146, 2019.

[15] I. O. Irtyshcheva, and D. V. Krylenko, "Institutional aspects of formation of the model of economic growth of the Black Sea region", Economic analysis, vol. 28, No. 1. pp. 62-70, 2018.

[16] V. V. Skupeyko, "Institutional features of functioning and ensuring competitiveness of agricultural enterprises", Uzhgorod National Scientific University Bulletin, Issue 17, Part 2, pp 77-84, 2018.

[17] V. Stadnyk, P. Izhevskiy, O. Zamazii, A. Goncharuk, and O. Melnichuk, "Factors of enterprises' strategic selection of participation forms in integration formations", Problems and Perspectives in Management, no. 16 (2), pp. 90-101, 2018. Doi.org/10.21511/ppm.16(2).2018.09.

[18] State Statistics Service of Ukraine: Volume of manufactured goods (goods, services) of enterprises by their size by types of economic activity [Online]. - Available: http://www.ukrstat.gov.ua.

[19] IMD World Competitiveness Center 2019 [Online]. - Available: http://cpi.ti-ukraine.org/

[20] Statistics Service of Ukraine Commodity structure of Ukraine's foreign trade. [Online]. - Available: http://www.ukrstat.gov.ua.

World Economic Forum 2019. [Online]. - Available http://www3.weforum.org/docs/GCR2017-2018/05FullReport/The Global CompetitivenessReport2017\%E2\%80\%932018.pdf. 